\title{
Hepatotoxicity associated with the ingestion of Centella asiatica
}

\author{
O. A. Jorge and A. D. Jorge \\ Gastroenterology Department. "Hospital Español”. Mendoza. Argentina
}

Jorge OA, Jorge AD. Hepatotoxicity associated with the ingestion of Centella asiatica. Rev Esp Enferm Dig 2005; 97: 115-124.

\begin{abstract}
Background: hepatotoxicity due to herbal remedies is being increasingly recognized. Centella asiatica (Centella asiatica Linn Urban) is commercialized for multiple conditions. Its active principles are pentacyclic triterpenic saponosides (asiaticoside, madecassoside).

Clinical case studies: we present three women (61, 52 and 49 years old) who developed jaundice after taking Centella asiatica for 30, 20 and 60 days. Respective laboratory tests: ALT: 1193, 1694 and 324 U/L; ALP: 503, 472 and 484 U/L; bilirubin: 4.23, 19.89 and $3.9 \mathrm{mg} / \mathrm{dl}$. The first patient also had ASMA 1/160 and AMA 1/320.

Respective pathological diagnoses: granulomatous hepatitis with marked necrosis and apoptosis; chronic hepatitis with cirrhotic transformation and intense necroinflammatory activity, and granulomatous hepatitis.

All patients improved with Centella asiatica discontinuation, and ursodeoxycholic acid $10 \mathrm{mg} / \mathrm{kg} /$ day.

The first patient took Centella asiatica again, with recurrence of the damage. The second one had taken this herb a year before.

Conclusions: many plants synthesize hepatotoxic compounds. Germander, Skullcap and Glycyrrhizin contain di- or triterpenic active principles, which can produce hepatic injury by promoting apoptosis and altering cell membranes. We hypothesize that these mechanisms may have resulted in injuries associated with Centella asiatica. The presence of autoantibodies and granulomas also favors an immune-mediated mechanism. Ursodeoxycholic acid has anti-apoptotic properties, but we cannot rule out that Centella asiatica discontinuation alone may have resulted in patient improvement.
\end{abstract}

Recibido: 01-06-04.

Aceptado: 27-07-04.

Correspondencia: Oliver A. Jorge. Videla Castillo, 1996. 5500 Mendoza. Argentina. Tel.: 0054-261-4231988. e-mail: oliverjorge@lanet.com.ar
Key words: Hepatotoxicity. Centella asiatica. Apoptosis. Ursodeoxycholic acid.

\section{INTRODUCTION}

Hepatotoxicity associated with herbal remedies is being increasingly recognized $(1,2)$. In recent years the use of these substances has increased in the Western world $(3,4)$. These herbs are considered healthy with no association with toxic effects (5).

The liver, responsible for their metabolism, is susceptible to damage by these herbal remedies (6).

Many plants come from the East, where they have been a part of traditional medicine in countries such as China and Japan $(7,8)$. Although these substances are perceived as relatively safe, about $1 \%$ of the people who use them may develop elevated hepatic enzymes (9). The most widely known compounds related to hepatic lesions are Ma-Huang $(10,11)$, Jin-Bu-Huan $(12,13)$, and SyoSaiko-To (14). They have been involved in lesions such as hepatocellular damage, autoimmune hepatitis, fulminant hepatitis, chronic hepatitis, and cirrhosis.

The herb Centella asiatica (Centella asiatica Linn Urban) comes from the Eastern world, especially India and Sri Lanka. For thousands of years it has been used in Ayurvedic medicine (15) to treat wound healing and leprosy, and as a psycho-physical regenerator and blood purifier (16-18).

Plants and extracts of this herb have active principles, namely pentacyclic triterpenic saponosides: mainly asiaticoside (ester of asiatic acid and a trisaccharide) and madecassoside (ester of madecassic acid and a trisaccharide). Other minor saponins are centelloside, brahmoside, brahminoside, and centellasaponins B, C and D (19-21).

At present Centella asiatica is used for dementias and cognitive disorders $(22,23)$, in the treatment of chronic 
venous insufficiency, diabetic microangiopathy and atherosclerotic plaques $(24,25)$, and in dermatological pathologies such as wound healing and scars (26), prevention of striae gravidarum (27), and psoriasis (28). It is commercialized for the treatment of obesity and cellulitis (19).

The use of Centella asiatica may be seemingly associated with the development of adverse effects such as contact dermatitis (related to active principles such as madecassoside) (29-31) and infertility (related to isothankuniside and thankuniside, which are present in extracts) (32). We have found no cases of hepatotoxicity associated with the ingestion of this herbal medicine in the literature.

We discuss three clinical case studies of hepatotoxicity related to the ingestion of Centella asiatica.

\section{CLINICAL CASES}

Case 1. A female, 61-year old patient with no medical history. She consulted for pain in the right hypochondrium, choluria, jaundice, asthenia, and generalized arthralgia. She had been ingesting tablets of Centella asiatica for 30 days to lose weight. At physical examination, she showed jaundice and painful hepatomegaly.

Laboratory tests (Table I): AST, 1020 U/L; ALT, 1193 $\mathrm{U} / \mathrm{L}$; alkaline phosphatase, $503 \mathrm{U} / \mathrm{L}$; total bilirubin (TB), $4.23 \mathrm{mg} / \mathrm{dl}$. ASMA, 1/160; AMA, 1/320. Abdominal ultrasound was normal.

Hepatic biopsy: granulomatous acute hepatitis, with marked cellular necrosis and apoptosis (eosinophilic degeneration), mainly in zone 3 , accompanied by lymphoplasmocytic infiltrate (Figs. 1 and 2).

She was administered ursodeoxycholic acid (UDCA) $10 \mathrm{mg} / \mathrm{kg} / \mathrm{day}$, and evolved favorably. Two months later she was asymptomatic and anicteric.

Laboratory tests: AST, $23 \mathrm{U} / \mathrm{L}$; ALT, $18 \mathrm{U} / \mathrm{L}$; alkaline phosphatase, $191 \mathrm{U} / \mathrm{L} ; \gamma \mathrm{GT}, 43 \mathrm{U} / \mathrm{L}$; TB, $1.18 \mathrm{mg} / \mathrm{dl}$; prothrombin activity, 100\%; ASMA (-); AMA (-). UDCA was discontinued, with a persisting good clinical and laboratory evolution.

Seven months later, she took Centella asiatica again for 2 weeks. She presented with pain in the right hypochondrium, jaundice and asthenia. Laboratory tests: prothrombin activity, 72\%; AST, $413 \mathrm{U} / \mathrm{L} ; \mathrm{ALT}, 481$ $\mathrm{U} / \mathrm{L}$; alkaline phosphatase, $383 \mathrm{U} / \mathrm{L} ; \gamma \mathrm{GT}, 68 \mathrm{U} / \mathrm{L} ; \mathrm{TB}$, $2.8 \mathrm{mg} / \mathrm{dl}$. Negative viral serology. Negative ANA, ASMA, and AMA.

Hepatic biopsy: similar lesions to those shown in the previous biopsy (Fig. 3).

She was treated with prednisone at decreasing doses, starting with $40 \mathrm{mg} / \mathrm{day}$, and UCDA $10 \mathrm{mg} / \mathrm{kg} / \mathrm{day}$. One month later she was asymptomatic and anicteric. Laboratory tests: prothrombin activity, 90\%; AST, $16 \mathrm{U} / \mathrm{L}$; ALT, $27 \mathrm{U} / \mathrm{L}$; alkaline phosphatase, $238 \mathrm{U} / \mathrm{L} ; \gamma \mathrm{GT}, 25 \mathrm{U} / \mathrm{L}$; TB, $0.6 \mathrm{mg} / \mathrm{dl}$. Medication was discontinued, with good clini-
Table I. Initial laboratory tests of clinical cases presented

\begin{tabular}{|c|c|c|c|}
\hline & Case No 1 & Case No 2 & Case No 3 \\
\hline Hemoglobin (g/dl) & 15 & 13.2 & 13 \\
\hline Leukocytes $\left(\mathrm{mm}^{3}\right)$ & 6000 & 5900 & 6400 \\
\hline $\mathrm{ESR}(\mathrm{mm} / \mathrm{h})$ & 3 & & 22 \\
\hline Prothrombin (PT) (\%) & 72 & 60 & 100 \\
\hline Glycemia (mg/dl) & 75 & 83 & 84 \\
\hline Uremia (mg/dl) & 10 & 12 & 22 \\
\hline AST (U/I) & 1020 & 1287 & 260 \\
\hline ALT (U/I) & 1193 & 1694 & 324 \\
\hline ALP (U/I) & 503 & 472 & 484 \\
\hline$\gamma G T(U / I)$ & 152 & 260 & 184 \\
\hline Direct bilirubin (DB) (mg/dl) & 2.85 & 15.11 & 2.5 \\
\hline Indirect bilirubin (IB) (mg/dl) & 1.38 & 4.78 & 1.4 \\
\hline Total bilirubin (TB) (mg/dl) & 4.23 & 19.89 & 3.9 \\
\hline Total proteins (TP) (g/dl) & 6.44 & 6.6 & 6.2 \\
\hline Albumin (ALB) (g/dl) & 3.59 & 3.46 & 3.8 \\
\hline Gamma globulin ( $\gamma G L O B)(g / d l)$ & 1.21 & 1.47 & 1.2 \\
\hline Cholesterol (mg/dl) & & 141 & \\
\hline Triglycerides (mg/dl) & & 146 & \\
\hline Total bile acids (TBA) $(\mu \mathrm{mol} / \mathrm{l})$ & & 174 & \\
\hline Anti-HAV IgM & $(-)$ & $(-)$ & $(-)$ \\
\hline Anti-HAV IgG & $(-)$ & $(-)$ & $(-)$ \\
\hline Anti-HCV & $(-)$ & $(-)$ & $(-)$ \\
\hline $\mathrm{HbsAg}$ & $(-)$ & $(-)$ & $(-)$ \\
\hline Anti-HBC & $(-)$ & $(-)$ & $(-)$ \\
\hline ANA & $(-)$ & $(-)$ & $(-)$ \\
\hline ASMA & $1 / 160$ & $(-)$ & $(-)$ \\
\hline AMA & $1 / 320$ & $(-)$ & $(-)$ \\
\hline Anti LKM $_{1}$ & $(-)$ & $(-)$ & $(-)$ \\
\hline
\end{tabular}

ESR: erythrocyte sedimentation rate; AST: normal value (n.v.) up to 40; ALT: n.v. up to 40; ALP: n.v. up to 301; $\gamma$ GT: n.v. up to 40; total bile acids: n.v. up to 6; ANA: antinuclear antibodies; ASMA: anti-smooth muscle antibodies; AMA: antimitochondrial antibodies; anti LKM : anti-liver-kidney microsomal antibodies.

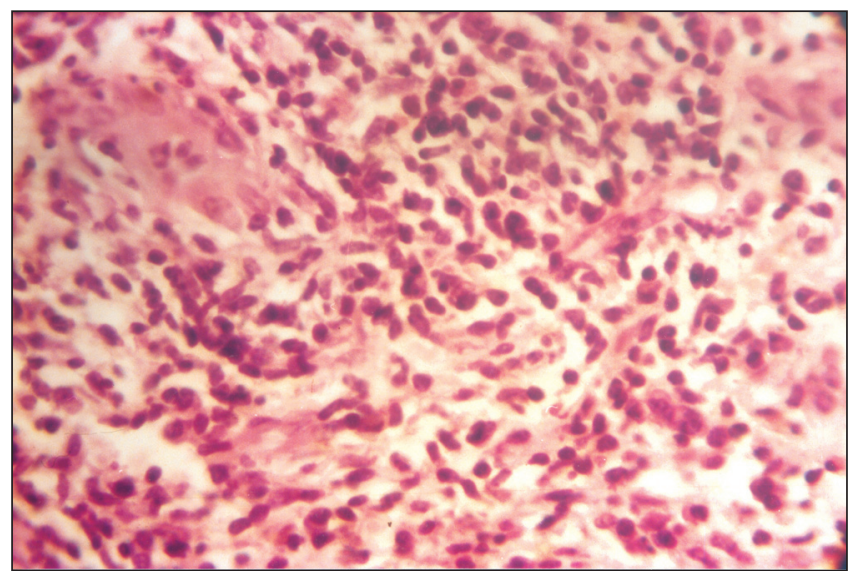

Fig. 1.- Anatomopathological image corresponding to clinical case No 1. We observed dense mononuclear inflammatory infiltrates and the presence of a multinucleated cell (Hematoxylin and eosin, x40). Imagen anatomopatológica correspondiente al caso clínico n¹. Observamos denso infiltrado inflamatorio mononuclear y la presencia de una célula multinucleada (Hematoxilina y eosina, 40x).

cal and laboratory evolution during follow-up for over 8 years. ASMA and AMA remained negative.

Case 2. A 52-year-old female patient who consulted for asthenia and anorexia followed by pruritus, choluria, acholia, and jaundice. At physical examination she 


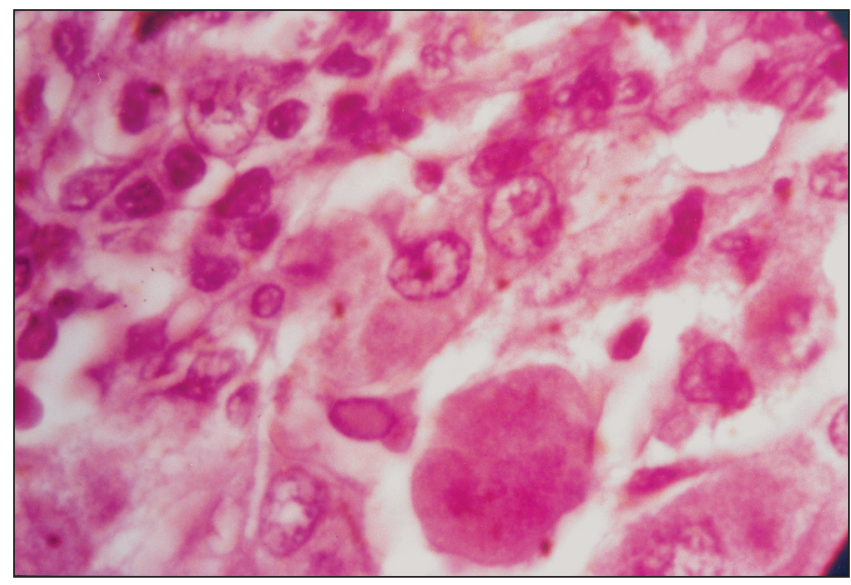

Fig. 2.- Anatomopathological image corresponding to clinical case No 1 We observed an acidophil body surrounded by swollen and ballooned hepatocytes and inflammatory cells (Hematoxylin and eosin, x100). Imagen anatomopatológica correspondiente al caso clínico $n^{\circ} 1$. Observamos un cuerpo acidófilo rodeado de hepatocitos tumefactos y balonizados y de células inflamatorias (Hematoxilina y eosina, 100x).

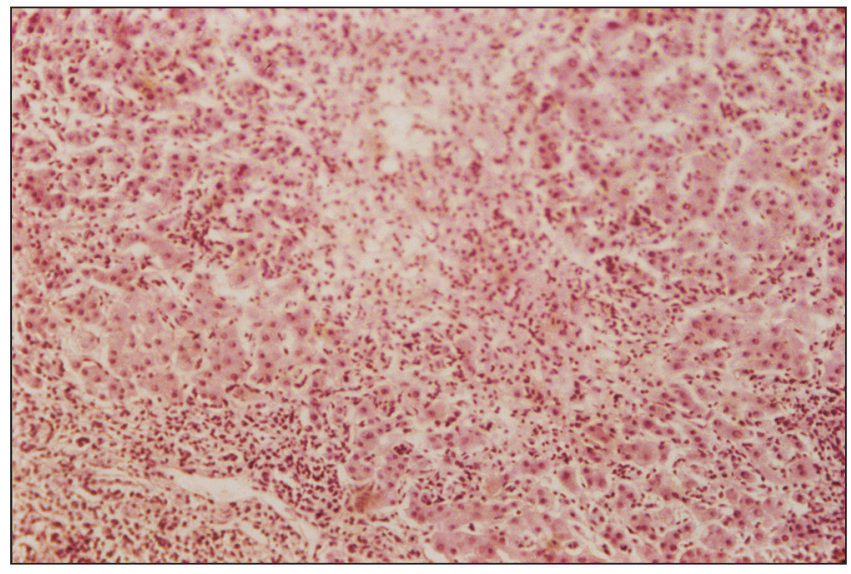

Fig. 3.- Anatomopathological image corresponding to clinical case No 1 after re-ingestion of Centella asiatica (rechallenge). We observed dense inflammatory infiltrates accompanied by injured hepatocytes distributed in the parenchyma (Hematoxylin and eosin, x10).

Imagen anatomopatológica correspondiente al caso clínico $n^{\circ} 1$ después de reingerir Centella asiática (recarga). Observamos denso infiltrado inflamatorio acompañado de hepatocitos lesionados distribuidos por el parénquima (Hematoxilina y eosina, 10x).

showed jaundice and painful hepatomegaly of augmented consistency. She said she had ingested Centella asiatica tablets for three weeks to lose weight. She reported a similar history one year before, accompanied by elevated hepatic enzymes and a negative viral serology, when taking Centella asiatica for six months. On that occasion jaundice had disappeared one month after discontinuation of this compound. There was no history of blood transfusion, alcohol or other medication consumption, or other pathologies.

Laboratory tests (Table I): prothrombin activity, 60\%; AST, $1287 \mathrm{U} / \mathrm{I}$; ALT, $1694 \mathrm{U} / \mathrm{L}$; alkaline phosphatase,
$472 \mathrm{U} / \mathrm{L} ; \mathrm{TB}, 19.89 \mathrm{mg} / \mathrm{dl}$; TBA: 174 umol/l. Abdominal ultrasound: normal.

Hepatic biopsy: chronic hepatitis with cirrhotic transformation, with cholestasis and intense necroinflammatory activity accompanied by granulomas and areas of necrosis and eosinophilic degeneration (Figs. 4 and 5).

She was administered UDCA $10 \mathrm{mg} / \mathrm{kg} /$ day and evolved favorably. Two months later she was asymptomatic and anicteric. Laboratory tests: prothrombin activity, 100\%; AST: $32 \mathrm{U} / \mathrm{L}$; ALT, $40 \mathrm{U} / \mathrm{L}$; alkaline phosphatase, $221 \mathrm{U} / \mathrm{L} ; \gamma \mathrm{GT}, 30 \mathrm{U} / \mathrm{L} ; \mathrm{TB}, 1 \mathrm{mg} / \mathrm{dl}$; TBA, 1.82 $\mu \mathrm{mol} / \mathrm{l}$.

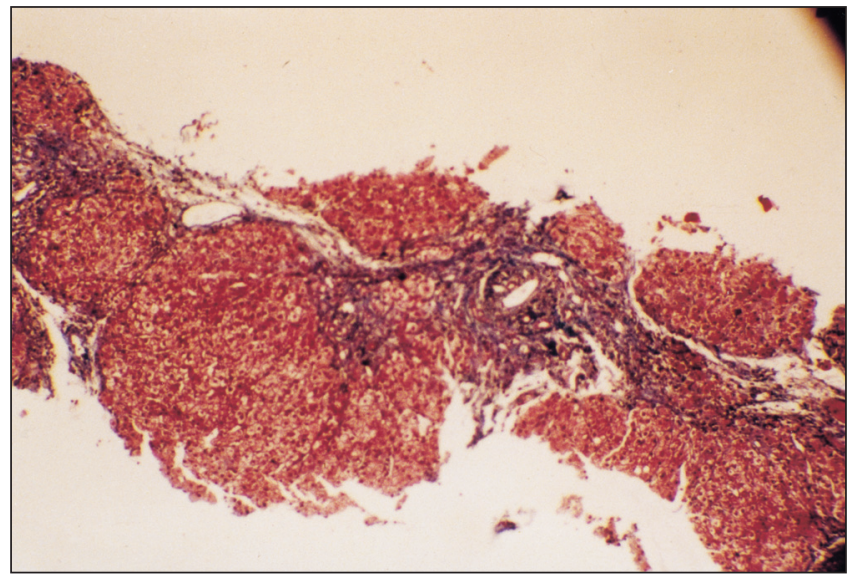

Fig. 4.- Anatomopathological image corresponding to clinical case No 2. We observed the presence of fibrosis and formation of pseudolobules (Trichrome, x3).

Imagen anatomopatológica correspondiente al caso clínico $n^{\circ} 2$. Observamos la presencia de fibrosis y la formación de pseudolobulillos (Tricrómico, 3x).

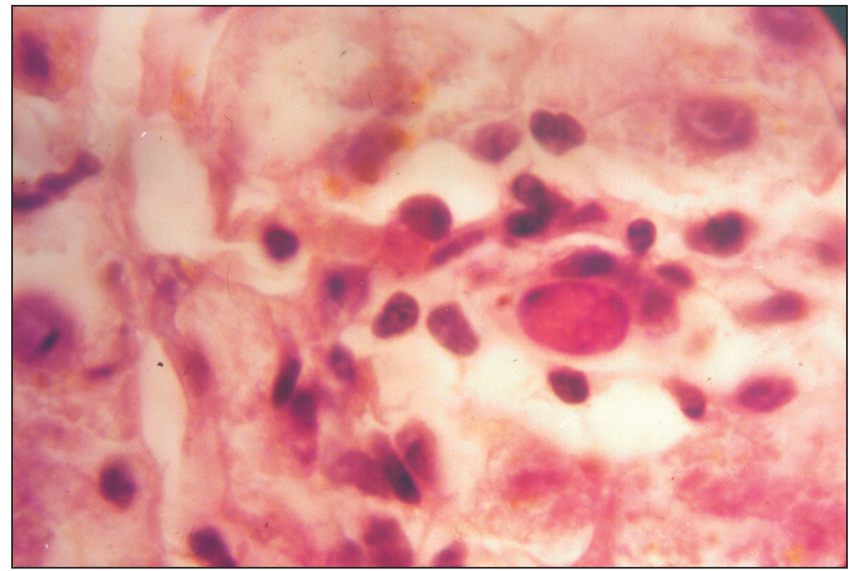

Fig. 5.- Anatomopathological image corresponding to clinical case No 2.We observed a hepatocyte with acidophil coloration and condensation of nuclear chromatin surrounded by lymphocytes and swollen and ballooned cells (Hematoxylin and eosin, x100).

Imagen anatomopatológica correspondiente al caso clínico $n^{\circ} 2$. Observamos un hepatocito, con coloración acidófila y condensación de la cromatina nuclear, rodeado de linfocitos y de células tumefactas y balonizadas. (Hematoxilina y eosina, 100x). 
Evolution was good, with the patient remaining asymptomatic and without elevated liver enzymes during follow-up for more than five years.

Case 3. A 49-year-old female patient with no medical history. She consulted for pain in the right hypochondrium, jaundice and asthenia. She had ingested Centella asiatica tablets for 2 months in order to lose weight. At physical examination she showed jaundice and painful hepatomegaly.

Laboratory tests (Table I): AST, 260 U/L; ALT, 324 $\mathrm{U} / \mathrm{L}$; alkaline phosphatase, $484 \mathrm{U} / \mathrm{L}$; TB, $3.9 \mathrm{mg} / \mathrm{dl}$. Abdominal ultrasound: normal.

Hepatic biopsy: granulomatous hepatitis with areas of necrosis and eosinophilic degeneration in zone 3 , accompanied by lymphoplasmocytic infiltrate.

She was administered UDCA $10 \mathrm{mg} / \mathrm{kg} /$ day, and evolved favorably. One month later she was asymptomatic and anicteric. Laboratory tests: AST, $24 \mathrm{U} / \mathrm{I}$; ALT, $33 \mathrm{U} / \mathrm{L}$; alkaline phosphatase, $263 \mathrm{U} / \mathrm{L} ; \gamma \mathrm{GT}, 39 \mathrm{U} / \mathrm{L}, \mathrm{TB}$, $0.8 \mathrm{mg} / \mathrm{dl}$; prothrombin activity, $100 \%$. UDCA was discontinued, and a good clinical and laboratory evolution ensued during follow-up for one year.

\section{DISCUSSION}

Herbal remedies may give rise to toxicity in different tissues (33). Many plants synthesize alkaloids and cyclic compounds to prevent animals from eating them (34).

The liver metabolizes these substances through cytochrome P450. During biotransformation, metabolites are produced which react with macromolecules and damage hepatic cells or generate neoantigens, which trigger immune damage (35).

Terpenes are cyclic hydrocarbons constituted by isoprene units. They are distributed in the vegetable kingdom in the form of oxygenated derivatives (alcohols, aldehydes, carboxyl acids, esters) (36,37). Triterpenic saponosides are heterosides (formed by a carbohydrate and a non-glycosid group or aglycone) which can be toxic for animals (38). They alter cell membranes by interacting with their lipid layer and through their anti-ATPase power, thus disturbing sodium transport $(39,40)$.

Glycyrrhizin is a triterpenic saponoside present in herbal remedies like Syo-Saiko-To, which are associated with hepatotoxicity. The most characteristic lesions have been centrilobular necrosis and fibrosis in cases of prolonged consumption (14).

Germander (Teucrium chamaedrys) is a herb whose active principles are furane-neo-clerodane-diterpenoids. These are metabolized by CYP3A to reactive metabolites, which covalently bind to proteins and reduce intracellular concentrations of glutathione (GSH). This increases calcium concentration, and transglutaminase is activated to form aggregates with cytoskeleton proteins. Increased calcium activates endonucleases, which fragment nuclear DNA and favor apoptosis $(41,42)$.
Skullcap (Scutellaria Lateriflora) has neo-clerodanediterpenoid active principles like scutelaterins A, B, and C. These are metabolized to reactive compounds by CYP3A. They induce intracellular GSH depletion, calcium increase, and activation of transglutaminases and endonucleases. They favor mitochondrial permeability transition pore (MPTP) opening at the inner membrane and the rupture of the outer membrane, thus releasing cytochrome $c$ into the cytoplasm, activating caspases, and originating apoptosis (43).

Camphor contains cyclic terpenes associated with hepatotoxicity (44).

The active principles of Centella asiatica (asiaticoside, madecassoside) are triterpenic compounds belonging in the same family of vegetal hydrocarbons as the diterpenes in Germander and Skullcap, the glycyrrhizin triterpenic saponoside, and the cyclic terpenes of Camphor. We hypothesize that damage produced by Centella asiatica probably takes place through a similar mechanism to that of these herbs, with induction of apoptosis and death through an alteration of cell membranes. In this respect, the liver biopsies of our patients showed marked eosinophilic degeneration and cellular necrosis.

The etiological diagnosis of hepatotoxicity from herbal remedies and medications is based on clinical and chronological circumstantial evidences (45).

The gold standard is response to the re-administration of the chemical compound, which is called rechallenge. This must be produced in accidental circumstances, since it may be dangerous, especially when an immune mechanism is suspected. When positive (hepatic lesions develop again), this diagnosis may be suggested (46).

In cases discussed here, we observed a clinical and chronological sequence between consumption of Centella asiatica and the development of hepatic lesions. Moreover, in cases 1 and 2 unintentional rechallenge was positive.

The histopathological alterations that accompany hepatotoxicity from herbal remedies or medications have been classified according to the predominant type of lesion (47). One of the most frequent forms is acute hepatocellular injury with marked necrosis of hepatocytes and apoptosis, generally more intense in zones 2 and 3. It may be accompanied by an inflammatory infiltrate surrounding injured cells. There is a considerable increase of transaminases with respect to alkaline phosphatase. This may be related to mechanisms of dose-dependent, idiosyncratic or immunological toxicity. The chronic form is less frequent; it is associated with a more prolonged consumption of the substance, and is responsible for about $1 \%$ of chronic hepatitis and cirrhosis $(48,49)$.

In cases 1 and 3 the predominant lesion was of an acute hepatocellular type. The presence of granulomas and autoantibodies (ASMA and AMA) in case 1, and the relatively short time between re-ingestion of the substance and the development of symptoms in cases 1 and 2 , favor the possibility of an immune mechanism as a 
component of hepatotoxicity. These mechanisms have been involved as part of the etiology of hepatotoxicity from Germander (50) and herbs containing Skullcap and Glycyrrhizin, such as Syo-Saiko-To (51). In these cases were also observed the presence of autoantibodies and granulomas. In case 2 (where there had been a more prolonged previous consumption of Centella asiatica) we also observed a chronic hepatic injury associated with cholestasis.

Undefined environmental factors and an individual susceptibility associated with metabolic idiosyncracy (which in cases of hepatotoxicity from chlorpromazine, phenytoin, and Kava has been related to genetic defects in hepatic metabolism) may predispose to the development of hepatic lesions when ingesting herbal remedies $(52,53)$.

The treatment of hepatotoxicity due to herbal remedies consists of product discontinuation and hepatic function monitoring. In cases where hepatic insufficiency developed liver transplantation was performed $(54,55)$.

$\mathrm{N}$-acetylcysteine (NAC) has been used in hepatotoxicity produced by Pennyroyal oil (56). It is a glutathione precursor, which is the main antioxidant system of hepatocytes. The active principle of Pennyroyal (pulegone monoterpene) produces depletion of glutathione, thus favoring oxidative stress and apoptosis.

Ursodeoxycholic acid (UDCA) has hydrophilic and protective properties regarding membranes of hepatocytes. It is also a choleretic and immunomodulating agent, and is used in diseases associated with cholestasis (57).

UDCA prevents apoptosis and hinders increased permeability of the inner mitochondrial membrane by inhibiting the opening of MPTP. It binds to the pro-apoptotic protein $\mathrm{BAX}$, thus preventing its translocation towards the mitochondrial membrane, and decreases the release of cytochrome $\mathrm{c}$, thus inhibiting caspase activation $(58,59)$.

The use of inhibitors of the opening of mitochondrial MPTP (like UDCA) in cases where there is apoptosis, and of glutathione precursors (like NAC and S-adenosylmethionine) in cases of oxidative stress or glutathione depletion have been suggested as therapeutic strategies in cases of hepatotoxicity (60). A beneficial effect of UDCA has been observed in hepatitis induced by amoxycillin, non-steroidal anti-inflammatory drugs, and sulfamide (61).

In the cases discussed here, where there was extensive apoptosis in liver biopsies, the use of UDCA was associated with clinical improvement. However, we cannot rule out the possibility that it was the discontinuation of Centella asiatica alone what brought about improvement as observed.

Glucocorticoids have been used in severe hepatitis (sometimes of granulomatous type) induced by medications $(62,63)$. They have also been used in hepatitis associated with immune phenomena produced by Kava (53),
Ma-Huang (10) or Syo-Saiko-To (51). We decided to prescribe them in case 1 due to the potential severity of the histological and clinical history, and to its possible relation to immunological phenomena.

In conclusion, we believe that Centella asiatica should be taken into account as a potential etiology of hepatic injury associated with apoptosis and necrosis and, in some cases, with the development of autoantibodies. UDCA, because of its anti-apoptotic mechanism, may be useful in the treatment of this condition. These findings should be confirmed by other papers.

\section{REFERENCES}

1. Larrey D. Hepatotoxicity of herbal remedies. J Hepatol 1997; 26 (Supl. 1): 47-51.

2. Koff R. Herbal hepatotoxicity: revisiting a dangerous alternative. JAMA 1995; 273: 502 .

3. Seef L, Lindsay K, Bacon B, et al. Complementary and alternative medicine in chronic liver disease. Hepatology 2001; 34: 595-603.

4. Kessler R, Davis R, Foster D, et al. Long-term trends in the use of complementary and alternative medical therapies in the United States. Ann Intern Med 2001; 135: 262-8.

5. Eisenberg D, Kessler R, Van Rampay M, et al. Perceptions about complementary therapies relatives to conventional therapies among adults who use both: results from a national survey. Ann Intern Med 2001; 135: 344-51.

6. Stedman C. Herbal hepatotoxicity. Semin Liver Dis 2002; 22: 195 206.

7. Grahan-Brown R. Toxicity of Chinese herbal remedies. Lancet 1992; 340: 673-4.

8. Shimizu J. Sho-saiko-to: Japanese herbal medicine for protection against hepatic fibrosis and carcinonona. Gastroenterol Hepatol 2000; 15 (Supl.): D84-90.

9. Melchart D, Linde K, Weidenhammer W, et al. Liver enzyme elevation in patients treated with traditional Chinese medicine. JAMA 1999; 282: 28-9.

10. Borum M. Fulminant exacerbation of autoimmune hepatitis after the use of Ma-Huang. Am J Gastroenterol 2001; 96: 1654-5.

11. Nadir A, Agrawal S, King D, et al. Acute hepatitis associated with the use of a Chinese herbal product, Ma-Huang. Am J Gastroenterol 1996; 91: 1436-8.

12. Picciotta A, Campo N, Brizzolara R, et al. Chronic hepatitis induced by Jin Bu Huan. J Hepatol 1998; 28: 165-7.

13. Woolf G, Petronic L, Rojter S, et al. Acute hepatitis associated with the Chinese herbal product Jin Bu Huan. Ann Intern Med 1994; 121 : 729-35.

14. Itoh S, Marutani $\mathrm{K}$, Nishijima $\mathrm{T}$, et al. Liver injuries induced by herbal medicine, syo-saiko-to (xiao-chai-hu-tang). Dig Dis Sci 1995; 40: $1845-8$.

15. Brown D. Encyclopedia of herbs and their uses. Dorley Kindersley Pub. 1995.

16. PDR for herbal medicine. Mont Vale. NJ: $1^{\text {st }}$ ed. Medical Economics Co, 1999. p. 729.

17. Herbert D, Paramasivan C, Prabhakar R, et al. In vitro experiments with Centella asiatica: investigation to elucidate the effect of an indigenously prepared powder of this plant on the acid-fastness and viability of M tuberculosis. Indian J Lepr 1994; 66: 65-8.

18. Baily E. Treatment of leprosy. Nature 1945; 155: 601.

19. Morganti P, Fionda A, Elia V, et al. Extraction and analysis of cosmetic active ingredients from an anti-cellulitis transdermal delivery system by high-performance liquid chromatography. J Chromatogr Sci 1999; 37: 51-5.

20. Duke J. Handbook of Medicinal Herbs. Boca Raton, Fl CRC Press, 1985.

21. Brinkhaus B, Lindner M, Schuppan D, et al. Chemical, pharmacological and clinical profile of the East Asian medical plant centella asiatica. Phytomedicine 2000; 7: 427-48. 
22. Lee M, Kim S, Sung S, et al. Asiatic acid derivatives protect cultured cortical neurons from glutamate-induced excitotoxicity. Res Commun Mol Pathol Pharmacol 2000; 108: 75-86.

23. Mook-Jung I, Shin JE. Protective effects of asiaticoside derivates against beta-amyloid neurotoxicity. J Neurosci Res 1999; 58: 417 25 .

24. Incandela L, Cesarone M, Cacchio M, et al. Total triterpenic fraction of centella asiatica in chronic venous insufficiency and in high-perfusion microangiopathy. Angiology 2001; 52 (Supl. 2): s9-13.

25. Cesarone MR, Incandela L, DeSanctis MT, et al. Evaluation of treatment of diabetic microangiopathy with total triterpenic fraction of centella asiatica: a clinical prospective randomized trial with a microcirculatory model. Angiology 2001; 52 (Supl. 2): s49-54.

26. Widgerow A, Chait L, Stals R, et al. New innovations in scar management. Aesthetic Plast Surg 2000; 24: 227-34.

27. Young G, Jewell D. Creams for preventing stretch mark in pregnancy. Cochrane Database Syst Rev 2000; 2: CD000066.

28. Sampson J, Ramon A, Karlsen G, et al. In vitro keratinocyte anti proliferant effect o Centella asiatica extract and triterpenoid saponins. Phytomedicine 2001; 8: 230-5.

29. Gonzalo Garijo M, Revenga Arnanz F, Bobadilla González P. Allergic contact dermatitis due to Centella asiatica: a new case. Allergon Inmunopathol 1996; 24: 132-4

30. Bilbao J, Aguirre A, Zabala R, et al. Allergic contact dermatitis from butosyethyl nicotinic acid and Centella asiatica extract. Contact Dermatitis 1995; 33: 435-6.

31. Eun HC, Lee AY. Contact dermatitis due to madecassol. Contact dermatitis $1985 ; 13: 310-3$.

32. Duta T, Basu UP. Crude extract of centella asiatica and products derived from its glycosides as oral antifertility agents. Ind J Exp Biol 1968; 6: 181 .

33. Desmet PAGM. Herbal remedies. N Engl J Med 2002; 347: 2046-56.

34. Kaplowitz N. Hepatotoxicity of herbal remedies: insights into the intricacies of plant-animal warfare and cell death. Gastroenterology 1997; 113: 1408-12

35. Watson WH, Dahm LJ, Jones DP. Mechanisms of chemically induced liver disease. En Zakim D, Boyer TD. Hepatology. A text book of Liver Disease. Philadelphia: Saunders, 2003. p. 739-53.

36. Terpenos. Enciclopedia Visor Edición Latinoamericana. Buenos Aires: Visor Easa, 1999.

37. Combinaciones alicíclicas. En: Química General. Enciclopedia Labor. Barcelona: Ed. Labor S.A., 1963; Tomo II: 517-22.

38. Sesquiterpene. Polyterpene. Sterine. Vitamine. En: Karrer P. Lehrbuch der organischen CEIME. Stuttgart: Thieme Verlag, 1963. p. 726-74.

39. Mulet L. Estudio etnobotánico de la provincia de Castellón. Castellón: Diputación Provincial, 1991.

40. Saponinas y saponósidos. En: Mulet L. Flora tóxica de la Comunidad Valenciana. Castellón. Diputación Provincial, 1997.

41. Fau D, Lekehal M, Farrel G, et al. Diterpenoids from germander, an herbal medicine, induce apoptosis in isolated rat hepatocytes. Gastroenterology 1997; 113: 1334-46.

42. Lekehal M, Pessayre D, Lereau JM, et al. Hepatotoxicity of the herbal medicine germander: metabolic activation of its furano diterpenoids by cytocrome P450 3A depletes cytoskeleton-associated protein thiols and forms plasma membrane blebs in rat hepatocytes. Hepatology 1996; 24: 212-8.
43. Haouzi D, Lekehal M, Moreau A, et al. Cytochrome P450-generated reactive metabolites cause mitochondrial permeability transition, caspase activation, and apoptosis in rat hepatocytes. Hepatology 2000; 32: 303-11.

44. Uc A, Bishop WP, Sanders KD. Camphor hepatotoxicity. South Med J 2000; 93: 596-8.

45. Larrey D. Epidemiology and individual susceptibility to adverse drug reactions affecting the liver. Semin Liver Dis 2002; 22: 145-55.

46. Benichou C, Danan G, Flahault A. Causality assessment of adverse reactions to drugs-II. An original model for validation of drug causality assessment methods: case reports with positive rechallenge. J Clin Epidemiol 1993; 46: 1331-6.

47. Larrey D. Drug-induced liver diseases. J Hepatol 2000; 32: 77-88.

48. Bissell DM, Gores GJ, Laskin DL, et al. Drug-induced liver injury: mechanism and test systems. Hepatology 2001; 33: 1009-13.

49. Kaplowitz N. Causality assessment versus guilt-by-association in drug hepatotoxicity. Hepatology 2001; 33: 308-9.

50. DeBerardinis V, Moulis C, Maurice M, et al. Human microsomal epoxide hydrolase is the target of germander-induced autoantibodies on the surface of human hepatocytes. Mol Pharmacol 2000; 58: 54251.

51. Kamiyama T, Nauchi T, Kojima S, et al. Autoimmune hepatitis triggered by administration of an herbal medicine. Am J Gastroenterol 1997; 92: 703-4.

52. Spielberg SP. In vitro assessment of pharmacogenetic susceptibility to toxic drug abolites in humans. Federation Proc 1984; 43: 2308-13.

53. Stickel F, Baumüller HM, Seitz K, et al. Hepatitis induced by kava. J Hepatol 2003; 39: 62-7.

54. Mattei A, Rucay P, Samuel D, et al. Liver transplantation for acute liver failure after herbal medicine (teucrium polium) administration. J Hepatol 1995; 22: 597

55. Yoshida EM, McLean CA, Cheng ES, et al. Chinese herbal medicine, fulminant hepatitis and liver transplantation. Am J Gastroenterol 1996; 91: 2647-8.

56. Anderson IB, Mullen WH, Meeker JE, et al. Pennyroyal toxicity: Measurement of toxic metabolites in two cases and review of the literature. Ann Intern Med 1996; 124: 726-34.

57. Poupon RE, Bonnand AM, Chretien Y, et al. Ten-year survival in ursodeoxycholic acid-treated patients with primary biliary cirrhosis. Hepatology 1999; 29: 1668-71.

58. Lazaridis KN, Gores GJ, Lindor KD. Ursodeoxycholic acid: "mechanisms of action and clinical use in hepatobiliary disorders". J Hepatol 2001; 35: 134-46.

59. Rodrigues CMP, Fan G, Ma X, et al. A novel role for ursodeoxycholic acid in inhibiting apoptosis by modulating mitochondrial membrane perturbation. J Clin Invest 1998; 101: 2790-9.

60. Kaplowitz N. Biochemical and cellular mechanisms of toxic liver injury. Sem Liver DIS 2002; 22: 137-44.

61. Guma C, Thome N, Viola L, et al. Tratamiento con ácido ursodeoxicólico en la hepatitis por drogas: Resultados de un estudio piloto y controlado. Resúmenes del XII Congreso Argentino de Hepatología: Buenos Aires, 2003 Jul 1-4.

62. Farrell GC. Drug-induced liver disease. Edinburgh, Churchill Livingstone, 1994. p. 513-8.

63. Moore DH, Benson GD. Prolonged halothane hepatitis: prompt resolution of severe lesion with corticosteroid therapy. Dig Dis Sci 1986; 31: 1269-7. 


\title{
Hepatotoxicidad asociada al consumo de Centella asiática
}

\author{
O. A. Jorge y A. D. Jorge \\ Servicio de Gastroenterología. Hospital Español de Mendoza. Argentina
}

\section{RESUMEN}

Introducción: la hepatotoxicidad por hierbas medicinales es reconocida cada vez más frecuentemente. Centella asiática (Centella asiatica Linn Urban) es comercializada para múltiples afecciones. Sus principios activos son saponósidos pentacíclicos triterpénicos (asiaticósido, madecasósido).

Casos clínicos: presentamos 3 mujeres (61, 52 y 49 años) que presentaron ictericia después de consumir Centella asiática por 30, 20 y 60 días. Analíticas respectivas: ALT: 1193, 1694 y 324 U/l; FAL: 503, 472 y 484 U/l; bilirrubina: 4,23, 19,89 y $3,9 \mathrm{mg} / \mathrm{dl}$. La primera presentó ASMA 1/160 y AMA 1/320.

Diagnósticos anatomopatológicos: respectivamente hepatitis granulomatosa con marcada necrosis y apoptosis; hepatitis crónica con transformación cirrótica e intensa actividad necroinflamatoria y hepatitis granulomatosa.

Todas mejoraron al suspender Centella asiática y con ácido ursodeoxicólico $10 \mathrm{mg} / \mathrm{kg} /$ día.

La primera volvió a ingerir Centella asiática, repitiendo las lesiones. La segunda había ingerido esta sustancia un año antes.

Conclusiones: muchos vegetales sintetizan compuestos hepatotóxicos. Camedrio, escutelaria y glicirricina poseen principios activos di- o triterpénicos que pueden lesionar el hígado promoviendo apoptosis y alterando membranas celulares. Hipotetizamos que estos mecanismos pueden haber producido las lesiones asociadas a Centella asiática. La presencia de autoanticuerpos y granulomas también favorecen un mecanismo inmunológico. El ácido ursodeoxicólico posee propiedades antiapoptóticas, aunque no podemos descartar que la sola discontinuación de Centella asiática haya determinado la mejoría de las pacientes.

Palabras clave: Hepatotoxicidad. Centella asiática. Apoptosis. Ácido ursodeoxicólico.

\section{INTRODUCCIÓN}

La hepatotoxicidad asociada a hierbas medicinales se reconoce cada vez más frecuentemente $(1,2)$. En los últimos años ha aumentado el uso de estas sustancias en Occidente $(3,4)$. Estas hierbas son percibidas como saludables, no asociándoselas a efectos tóxicos (5).

El hígado, encargado de su metabolización, es susceptible al daño que pueden producir las hierbas medicinales (6).

Muchas hierbas provienen de Oriente, donde han formado parte de la medicina tradicional de países como China y Japón $(7,8)$. Aunque estas sustancias son consideradas relativamente seguras, alrededor del $1 \%$ de los que las consumen pueden elevar las enzimas hepáticas (9). Los compuestos más conocidos relacionados con lesiones hepáticas son Ma-Huang (10,11), Jin-Bu-Huan $(12,13)$ y Syo-Saiko-To (14). Han sido implicados en lesiones como daño hepatocelular, hepatitis autoinmune, hepatitis fulminante, hepatitis crónica y cirrosis.

La hierba Centella asiática (Centella asiatica Linn Urban) proviene de Oriente, fundamentalmente India y Sri Lanka. Durante milenios ha sido utilizada en la medicina ayurvédica (15) para tratamientos de cicatrización de heridas, lepra, como revitalizador psico-físico y purificador de la sangre (16-18).

Planta y extractos de esta hierba contienen principios activos que son saponósidos pentacíclicos triterpénicos: principalmente asiaticósido (éster del ácido asiático y un trisacárido) y madecasósido (éster del ácido madecásico y un trisacárido). Otras saponinas minoritarias son centellósido, brahmósido, brahminósido y centellosaponinas B, C y D (19-21).

Actualmente, Centella asiática es utilizada en demencias y trastornos cognitivos $(22,23)$, en el tratamiento de insuficiencia venosa crónica, de microangiopatía diabética y de placas arterioescleróticas $(24,25)$, en patologías dermatológicas como cicatrización de heridas y escaras (26), prevención de estrías del embarazo (27) y psoriasis (28). Se comercializa para el tratamiento de obesidad y celulitis (19).

La utilización de Centella asiática estaría relacionada con la aparición de efectos adversos, como dermatitis de contacto (relacionada a sus principios activos, como el madecasósido) (29-31) e infertilidad (asociada a isotancunósidos y tancunósidos presentes en sus extractos) (32). No hemos encontrado descriptos casos de hepatotoxicidad asociados a la ingesta de esta hierba medicinal.

A continuación presentamos tres casos clínicos de hepatotoxicidad relacionados a la ingesta de Centella asiática.

\section{CASOS CLÍNICOS}

Caso 1. Paciente femenina, 61 años, sin antecedentes patológicos. Consultó por dolor en hipocondrio derecho, coluria, ictericia, astenia y artralgias generalizadas. Había 
ingerido tabletas de Centella asiática durante 30 días para bajar de peso. Al examen físico destacó ictericia y hepatomegalia dolorosa.

Analítica (Tabla I): destacó AST: 1020 U/l; ALT: 1193 U/1 ; FAL: $503 \mathrm{U} / \mathrm{l}$; bilirrubina total (BT): 4,23 mg/dl. ASMA: 1/160; AMA: 1/320. Ecografía abdominal normal.

Tabla I. Analítica inicial de los casos clínicos presentados

\begin{tabular}{|c|c|c|c|}
\hline & Caso $n^{\circ} 1$ & Caso $n^{\circ} 2$ & Caso $n^{\circ} 3$ \\
\hline Hemoglobina (g/dl) & 15 & 13,2 & 13 \\
\hline Leucocitos $\left(\mathrm{mm}^{3}\right)$ & 6000 & 5900 & 6400 \\
\hline VSG $(\mathrm{mm} / \mathrm{h})$ & 3 & & 22 \\
\hline Protrombina (TP) (\%) & 72 & 60 & 100 \\
\hline Glucemia (mg/dl) & 75 & 83 & 84 \\
\hline Uremia (mg/dl) & 10 & 12 & 22 \\
\hline AST (U/I) & 1020 & 1287 & 260 \\
\hline $\mathrm{ALT}(\mathrm{U} / \mathrm{l})$ & 1193 & 1694 & 324 \\
\hline $\mathrm{FAL}(\mathrm{U} / \mathrm{l})$ & 503 & 472 & 484 \\
\hline$\gamma \mathrm{GT}(\mathrm{U} / \mathrm{l})$ & 152 & 260 & 184 \\
\hline Bilirrubina directa (BD) (mg/dl) & 2,85 & 15,11 & 2,5 \\
\hline Bilirrubina indirecta (BI) (mg/dl) & 1,38 & 4,78 & 1,4 \\
\hline Bilirrubina total (BT) (mg/dl) & 4,23 & 19,89 & 3,9 \\
\hline Proteínas totales (PT) (g/dl) & 6,44 & 6,6 & 6,2 \\
\hline Albúmina (ALB) (g/dl) & 3,59 & 3,46 & 3,8 \\
\hline Gamma globulinas ( $\gamma \mathrm{GLOB})(\mathrm{g} / \mathrm{dl})$ & 1,21 & 1,47 & 1,2 \\
\hline Colesterol (mg/dl) & & 141 & \\
\hline Triglicéridos (mg/dl) & & 146 & \\
\hline Ácidos biliares totales (ABT) ( $\mu \mathrm{mol} / \mathrm{l})$ & & 174 & \\
\hline Anti-VHA IgM & $(-)$ & $(-)$ & $(-)$ \\
\hline Anti-VHA IgG & $(-)$ & $(-)$ & $(-)$ \\
\hline Anti-VHC & $(-)$ & $(-)$ & $(-)$ \\
\hline $\mathrm{HBsAg}$ & $(-)$ & $(-)$ & $(-)$ \\
\hline Anti-HBC & $(-)$ & $(-)$ & $(-)$ \\
\hline ANA & $(-)$ & $(-)$ & $(-)$ \\
\hline ASMA & $1 / 160$ & $(-)$ & $(-)$ \\
\hline AMA & $1 / 320$ & $(-)$ & $(-)$ \\
\hline Anti $\mathrm{LKM}_{1}$ & $(-)$ & $(-)$ & $(-)$ \\
\hline
\end{tabular}

VSG: velocidad de sedimentación globular. AST: valor normal hasta 40; ALT: v.n. hasta 40; FAL: v.n. hasta 301; $\gamma$ GT: v.n. hasta 40; ácidos biliares totales: v.n. hasta 6. ANA: anticuerpos antinúcleo; ASMA: anticuerpos antimúsculo-liso; AMA anticuerpos antimitocondriales; Anti $\mathrm{LKM}_{1}$ : anticuerpos antimicrosomas hígadoriñón.

Biopsia hepática: hepatitis aguda granulomatosa, con marcada necrosis celular y apoptosis (degeneración eosinofílica), principalmente en zona 3, acompañada de infiltrado linfoplasmocitario (Figs. 1 y 2).

Fue medicada con ácido ursodeoxicólico (AUDC) 10 $\mathrm{mg} / \mathrm{kg} / \mathrm{día}$, evolucionando favorablemente. Dos meses después, estaba asintomática y anictérica. Analítica: AST: $23 \mathrm{U} / 1$; ALT: $18 \mathrm{U} / \mathrm{l}$; FAL: $191 \mathrm{U} / \mathrm{l}$; $\gamma \mathrm{GT}$ : $43 \mathrm{U} / \mathrm{l}$; BT: $1,18 \mathrm{mg} / \mathrm{dl}$; TP: 100\%; ASMA(-); AMA(-). Se suspendió AUDC, persistiendo buena evolución clínica y analítica.

Siete meses más tarde, vuelve a ingerir Centella asiática durante 2 semanas. Presentó dolor en hipocondrio de- recho, ictericia y astenia. Analítica: TP: 72\%; AST: 413 U/l; ALT: 481 U/l; FAL: 383 U/l; $\gamma$ GT: 68 U/l; BT: 2,8 $\mathrm{mg} / \mathrm{dl}$. Serologías virales negativas. ANA, ASMA y AMA negativos.

Biopsia hepática: lesiones similares a las de biopsia anterior (Fig. 3).

Fue medicada con prednisona a dosis decreciente, comenzando por $40 \mathrm{mg} /$ día y AUDC $10 \mathrm{mg} / \mathrm{kg} /$ día. Un mes después estaba asintomática y anictérica. Analítica: TP: 90\%; AST: 16 U/l; ALT: 27 U/l; FAL: 238 U/l; $\gamma$ GT: 25 U/l; BT: 0,6 mg/dl. Se suspendió medicación, persistiendo buena evolución clínica y analítica, en controles posteriores durante más de 8 años. ASMA y AMA persistieron negativos.

Caso 2. Paciente femenina, 52 años. Consultó por astenia y anorexia seguidos de prurito, coluria, acolia e ictericia. Al examen físico destacó ictericia y hepatomegalia dolorosa de consistencia aumentada. Refirió ingesta de tabletas de Centella asiática, desde hacía 3 semanas, para adelgazar. Relató haber presentado cuadro clínico similar un año antes, acompañado de elevación de enzimas hepáticas y serologías virales negativas, al tomar Centella asiática durante seis meses. En esa oportunidad, la ictericia desapareció después de un mes de suspender dicho compuesto. No había antecedentes de transfusiones sanguíneas, ni ingesta alcohólica o de otros fármacos, ni de otras patologías.

Analítica (Tabla I): destacó TP 60\%; AST: 1287 U/l; ALT: $1694 \mathrm{U} / \mathrm{l}$; FAL: $472 \mathrm{U} / \mathrm{l}$; BT: 19,89 mg/dl; ABT: $174 \mu \mathrm{mol} / \mathrm{l}$. Ecografía abdominal normal.

Biopsia hepática: hepatitis crónica con transformación cirrótica, con colestasis e intensa actividad necroinflamatoria, acompañada de granulomas y de áreas de necrosis y degeneración eosinofílica (Figs. 4 y 5).

Fue medicada con AUDC $10 \mathrm{mg} / \mathrm{kg} /$ día evolucionando favorablemente. Dos meses después estaba asintomática y anictérica. Analítica: TP 100\%; AST: 32 U/l; ALT: $40 \mathrm{U} / \mathrm{l}$; FAL: $221 \mathrm{U} / \mathrm{l}$; $\gamma \mathrm{GT}$ : $30 \mathrm{U} / \mathrm{l}$; BT: $1 \mathrm{mg} / \mathrm{dl}$; ABT: $1,82 \mu \mathrm{mol} / 1$.

La evolución posterior fue buena, permaneciendo asintomática y no elevándose las enzimas hepáticas en controles realizados durante más de cinco años.

Caso 3. Paciente femenina, 49 años, sin antecedentes patológicos. Consultó por dolor en hipocondrio derecho, ictericia y astenia. Había ingerido tabletas de Centella asiática durante 2 meses para bajar de peso. Al examen físico destacó ictericia y hepatomegalia dolorosa.

Analítica (Tabla I): destacó AST: 260 U/1; ALT: 324 U/l; FAL: $484 \mathrm{U} / \mathrm{l}$; BT: 3,9 mg/dl. Ecografía abdominal normal.

Biopsia hepática: hepatitis granulomatosa, con áreas de necrosis y degeneración eosinofílica en zona 3, acompañadas de infiltrado linfoplasmocitario.

Fue medicada con AUDC $10 \mathrm{mg} / \mathrm{kg} /$ día, evolucionando favorablemente. Un mes después se encontraba asintomática y anictérica. Analítica: AST: $24 \mathrm{U} / \mathrm{l}$; ALT: $33 \mathrm{U} / \mathrm{l}$; FAL: $263 \mathrm{U} / \mathrm{l}$; $\gamma \mathrm{GT}$ : $39 \mathrm{U} / \mathrm{l}$; BT: 0,8 mg/dl; 
TP: $100 \%$. Se suspendió AUDC, persistiendo buena evolución clínica y analítica en controles realizados durante un año.

\section{DISCUSIÓN}

Las hierbas medicinales pueden producir toxicidad en diferentes tejidos (33). Muchos vegetales sintetizan alcaloides y compuestos cíclicos para preservarse contra animales que intentan alimentarse de ellos (34).

El hígado metaboliza estas sustancias a través del citocromo P450. En la biotransformación se producen metabolitos que reaccionan con macromoléculas y dañan células hepáticas, o generan neoantígenos que desencadenan daño inmunológico (35).

Los terpenos son hidrocarburos cíclicos constituidos por unidades de isopreno. Están difundidos en el reino vegetal, sobre todo en forma de derivados oxigenados (alcoholes, aldehídos, ácidos carboxílicos, ésteres) (36,37). Los saponósidos triterpénicos son heterósidos (formados por un carbohidrato y un grupo no glucídico o aglicona) que pueden ser tóxicos para los animales (38). Alteran las membranas celulares interaccionando con su capa lipídica y a través de su poder antiATPasa, perturbando el transporte de sodio $(39,40)$.

La glicirricina es un saponósido triterpénico presente en hierbas medicinales como Syo-Saiko-To, que ha sido asociada a hepatotoxicidad. Las lesiones más características han sido necrosis centrolobulillar y fibrosis en casos de ingesta prolongada (14).

El camedrio (Teucrium Chamaedrys) es una hierba cuyos principios activos son furano-neo-clerodano-diterpenoides. Estos son metabolizados por CYP3A a metabolitos reactivos que se unen de forma covalente a proteínas y reducen la concentración intracelular de glutation (GSH). Aumenta la concentración de calcio y se activa la transglutaminasa, la cual forma agregados con las proteínas del citoesqueleto. El aumento de calcio activa endonucleasas, fragmentando el DNA nuclear, favoreciendo la apoptosis $(41,42)$.

La escutelaria (Scutellaria Lateriflora) posee principios activos neo-clerodano-diterpenoides como las escutelaterinas A, B y C. Estas son metabolizadas a compuestos reactivos por CYP3A. Producen depleción intracelular de GSH, aumento de calcio y activación de transglutaminasa y de endonucleasas. Favorecen la apertura del poro de transición de la membrana interna mitocondrial (MPTP) y la ruptura de la membrana externa, liberándose citocromo c hacia el citoplasma, activándose las caspasas y ejecutándose la apoptosis (43).

El alcanfor contiene terpenos cíclicos asociados a hepatotoxicidad (44).

Los principios activos de Centella asiática (asiaticósido, madecasósido) son compuestos triterpénicos pertenecientes a la misma familia de hidrocarburos vegetales que los diterpenos de camedrio y de escutelaria, el saponósi- do triterpénico glicirricina y los terpenos cíclicos del alcanfor. Hipotetizamos que probablemente el daño producido por Centella asiática se lleve a cabo por un mecanismo similar al de estas hierbas, con inducción de apoptosis y de muerte por alteración de las membranas celulares. En este sentido, las biopsias hepáticas de nuestras pacientes mostraron marcada degeneración eosinofílica y necrosis celular.

El diagnóstico etiológico de hepatotoxicidad por hierbas medicinales y por fármacos se basa en evidencias circunstanciales cronológicas y clínicas (45).

El patrón oro es la respuesta a la readministración del compuesto químico, denominada recarga. Esta debe producirse en circunstancias accidentales, ya que puede ser peligrosa, sobre todo cuando se sospecha un mecanismo inmunológico. Cuando es positiva (volviéndose a producir lesiones hepáticas) el diagnóstico es muy sugestivo (46).

En los casos que presentamos, pudimos observar una secuencia cronológica y clínica entre ingesta de Centella asiática y aparición de lesiones hepáticas. Además, en los casos 1 y 2 , la recarga no intencionada fue positiva.

Las alteraciones histopatológicas que acompañan a la hepatotoxicidad por hierbas medicinales o por fármacos han sido clasificadas según el tipo de lesión predominante (47). Una de las formas más frecuentes es la injuria hepatocelular aguda con marcada necrosis de hepatocitos y apoptosis, generalmente más intensas en las zonas 2 y 3 del lobulillo. Suele acompañarse de infiltrado inflamatorio rodeando a las células lesionadas. Existe un sensible aumento de transaminasas con respecto a fosfatasa alcalina. Puede asociarse a mecanismos de toxicidad dosis-dependientes, de idiosincrasia o inmunológico. La forma crónica es menos frecuente, se asocia al consumo más prolongado de la sustancia y es responsable de alrededor del $1 \%$ de hepatitis crónicas y cirrosis $(48,49)$.

En los casos 1 y 3 la lesión predominante fue de tipo hepatocelular aguda. La presencia de granulomas y de autoanticuerpos (ASMA y AMA) en el caso 1, y el relativamente corto periodo de tiempo entre la reingestión de la sustancia y la aparición de síntomas en los casos 1 y 2 , favorece la posibilidad de un mecanismo inmunológico como componente de la hepatotoxicidad. Estos mecanismos han sido implicados como parte de la etiología de la hepatotoxicidad por camedrio (50) y por hierbas que contienen scutellaria y glicirricina, como Syo-Saiko-To (51). En estos casos también se observó la presencia de autoanticuerpos y de granulomas. En el caso 2 (donde había existido una ingesta anterior más prolongada de Centella asiática) además observamos un daño hepático crónico asociado a colestasis.

Factores ambientales no determinados y una susceptibilidad individual asociada a idiosincrasia metabólica (que en casos de hepatotoxicidad por clorpromazina, fenitoína y Kava, ha sido asociada a defectos genéticos en la metabolización hepática) pueden predisponer a desarrollar lesiones hepáticas al consumir hierbas medicinales $(52,53)$. 
El tratamiento de la hepatotoxicidad por hierbas medicinales va dirigido a la suspensión del producto implicado y al control de la función hepática. En casos donde se ha desarrollado insuficiencia hepática se ha procedido a un trasplante de hígado $(54,55)$.

La N-acetylcisteína (NAC) ha sido utilizada en la hepatotoxicidad por aceite de poleo (56). Es precursora del glutation, que es el principal sistema antioxidante de los hepatocitos. El principio activo del poleo (el monoterpeno pulegona) produce depleción de glutation, favoreciendo el estrés oxidativo y la apoptosis.

El ácido ursodeoxicólico (AUDC) posee propiedades hidrofílicas y protectoras de las membranas de los hepatocitos. También es colerético e inmunomodulador, siendo utilizado en enfermedades que se asocian a colestasis (57).

El AUDC previene la apoptosis impidiendo el aumento de la permeabilidad de la membrana interna de las mitocondrias por inhibición de la apertura del MPTP. Se fija a la proteína pro-apoptótica BAX, impidiendo su traslocación hacia la membrana mitocondrial y disminuye la liberación de citocromo c inhibiendo la activación de las caspasas $(58,59)$.

La utilización de inhibidores de la apertura del MPTP mitocondrial (como AUDC) en casos donde se evidencie apoptosis, y de precursores del glutation (como NAC y Sadenosylmetionina) en los casos de estrés oxidativo o asociados a depleción de esta sustancia, han sido sugeridas como estrategias terapéuticas en los casos de hepatotoxicidad (60). Se ha observado un efecto beneficioso del AUDC en hepatitis producidas por amoxicilina, antiinflamatorios no esteroideos y sulfamidas (61).

En los casos que presentamos, donde existía una importante apoptosis evidenciada en las biopsias hepáticas, la utilización de AUDC se asoció a una mejoría clínica. Sin embargo, no podemos descartar que la sola suspensión de Centella asiática haya determinado la mejoría observada.

Los glucocorticoides han sido utilizados en hepatitis severas (en ocasiones de tipo granulomatosas) producidas por fármacos $(62,63)$. También se han usado en hepatitis, asociadas a fenómenos inmunológicos, producidas por Kava (53), Ma-Huang (10) o Syo-Saiko-To (51). Decidimos prescribirlos en el caso 1 debido a la potencial severidad del cuadro clínico e histológico y a su posible relación con fenómenos inmunológicos.

En conclusión, creemos que Centella asiática debería ser tenida en cuenta como potencial etiología de daño hepático, asociado a apoptosis y necrosis y -en algunos casos- al desarrollo de autoanticuerpos. El AUDC, por su mecanismo antiapoptótico, podría ser de utilidad en su tratamiento. Estos hallazgos deberán ser confirmados por otros trabajos. 